\title{
Identification of CTX-M Gene Resistance on Bacteria Acinetobacter baumannii and Klebsiella pneumoniae in Pneumonia Patients in Haji Adam Malik Center Hospital, Medan, Indonesia
}

\author{
Safrina $\mathbf{S}^{*}$, Urip Harahap ${ }^{1}$, Fransiscus Ginting ${ }^{2}$ \\ ${ }^{1}$ Department of Pharmaceutical Pharmacology, Universitas Sumatera Utara \\ ${ }^{2}$ Department of Medicine, Haji Adam Malik Center Hospital
}

\begin{abstract}
A B S T R A C T
Objectives:To find out whether Acinetobacter baumannii and Klebsiella pneumoniae that cause pneumonia have Ceftriaxonresistant CTX-M coding genes.

Interventions: The method used in this study is a cross sectional prospective design and carried out prospectively in pneumonia patients who have medical record data on the diagnosis of pneumonia patients in the period January to September 2019 at the Haji Adam Malik General Hospital in Medan by taking sputum from the patient, then detected using Polymerase Chain Reaction (PCR) in the Integrated Laboratory of the Faculty of Medicine, Universitas Sumatra Utara.

Main outcomes measure: The resistance coding gene in Klebsiella pneumoniae with the percentage of CTX-M gene is $93.7 \%$ and Acinetobacter baumannii has a low percentage where the expression of CTX-M gene is $17.6 \%$.

Conclusion:-The distribution of the CTX-M gene in Klebsiella Pneumoniae is higher than that of Acinetobacter baumannii.
\end{abstract}

Keywords: CTX-M gene, Acinetobacter baumannii, Klebsiella pneumoniae, pneumonia

A R T I C L E I N F O: Received 31 Oct. 2019; $\quad$ Review Completed 09 Jan 2020; $\quad$ Accepted 27 Jan 2020; $\quad$ Available online 15 Feb. 2020

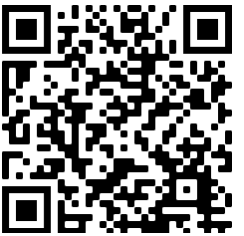

Cite this article as:

Safrina S*, Urip H, Fransiscus G, Identification of CTX-M Gene Resistance on Bacteria Acinetobacter baumannii and Klebsiella pneumoniae in Pneumonia Patients in Haji Adam Malik Center Hospital, Medan, Indonesia, Asian Journal of Pharmaceutical Research and Development. 2020; 8(1):25-28. DOI: http://dx.doi.org/10.22270/ajprd.v8i1.640

*Address for Correspondence:

Safrina S, Department of Pharmaceutical Pharmacology, Universitas Sumatera Utara, Medan 20155, Sumatera Utara, Indonesia

\section{INTRODUCTION}

$\mathrm{I}$ nfectious disease is one of the most common health problems faced by countries in the world, including Indonesia. One type of infectious disease that often occurs is respiratory infections ${ }^{1}$.

Streptococcus pneumoniae is the main cause (almost $50 \%$ of cases) in Community Acquired Pneumonia disease in the world. However, in developing countries, gram-negative bacteria are the most common cause. Based on studies of Community Acquired Pneumonia in Indonesia, Klebsiella pneumoniae is the main agent of this disease ${ }^{2}$.

Based on Microbiology culture data reports obtained from the Haji Adam Malik General Hospital from January to December 2017, with a total of 2622 patients. Pneumonia was the highest sepsis disease caused by gram negative bacteria Acinetobacter baumanii as much as $17.6 \%$ and the high rate of resistance to Ceftriaxon antibiotics is 56.3\% $78.5 \%$ in patients with pneumonia, so it can be a clinical consideration for not using ceftriaxon as therapy empirical.

CTX-M $\beta$-lactamase is an enzyme that has the ability of hydrophilic activity against Cefotaxim compared to other oxymino-beta-lactam subtractions such as Ceftazidime, Ceftriaxon or Cefepime. This enzyme gene mutation has a close relationship with the plasmid $\beta$-lactamase gene ${ }^{3}$.

Increased mortality associated with inappropriate antibiotic therapy against gram-negative bacteria. Extended Spectrum Beta-Lactamase (ESBL) which most commonly arises due to the mutation of the $\beta$-lactamase gene is CTX-M which is caused by the production of enzymes, such as AmpC or metallo- $\beta$-lactamse, and loss of porin ${ }^{3,4}$. 
Research in the United States in 1990 showed a prevalence of BLA CTX-M which is still rare and increased in 2000 by $25 \%$ and in 2005 to $90 \%$. Research in New York in 20102012 increased to $26.4 \%$. Research in Thailand CTX-M gene distribution is quite high at $87.3 \%$ and in Russia at $93 \%$. However, in a 2017 study at Surabaya Soetomo Hospital, the CTX-M distribution figure was $90 \%$. Shows ESBLproducing bacteria that are resistant to Ceftriaxon ${ }^{5,6}$.

This article discusses the results of identifying the CTX-M gene mutation that causes pneumonia in the Central General Hospital of Haji Adam Malik, Medan, Indonesia.

\section{METHODS}

This study uses the Cross Sectional Prospective Design method conducted prospectively to determine and determine the mutation of the bacterial gene that causes resistance to cephalosporin in Pneumonia patients who meet the criteria for the period January to September 2019 at Haji Adam Malik General Hospital Medan.

The study was approved by the Ethics Committee of the Faculty of Medicine, Universitas Sumatra Utara / H. Adam Malik Hospital.

\section{Population and Sample}

The population in this study was suspected Pneumonia Hospital of Haji Adam Malik Medan during the period from January to September 2019. Sampling as a research subject is carried out by using purposive sampling method. Sample selection is based on certain characteristics that are related to population characteristics that have been known previously. The sampling distribution curve will center on $10 \%$ of the population parameter and will have all the properties of a normal distribution ${ }^{7}$. The sample in this study amounted to 50 people based on the above theory.

\section{Sputum Sampling}

Sputum extraction was done in the morning before the patient brushes his teeth. Sputum was taken from the first cough (first cough) accommodated with a container in the form of a large-mouthed sterile pot and covered (Screw Cap Medium). Coughing sputum is checked, if it turns out that coughing is saliva, then it must be repeated. The selected sputum should contain special elements such as: cheese grains, blood, and other elements. Sputum samples are put into an ice cooler and then directly taken to the Integrated Laboratory of the Faculty of Medicine, Universitas Sumatera Utara to be used as research material for the identification of gene mutations that occur in bacteria that cause pneumonia. If the sample has not been used, it should be stored at $2-8^{\circ} \mathrm{C}$.

\section{Sputum Pneumonia Sample Extraction}

The sample is stored in an incubator of $30^{\circ} \mathrm{C}$ for 20 minutes, then the sample is prepared for the DNA extraction process $^{8}$. Pneumonia bacterial DNA extraction was carried out using Norgen Biotek ${ }^{\circledR}$ Sputum DNA Isolation Kit. The extraction results were tested for DNA purity by calculating ratios at wavelengths of 260 and $280 \mathrm{~nm}$ using a nanophotometer to obtain results of 1.8-2.0 which showed that bacterial DNA had high purity and could be amplified using PCR.

\section{CTX-M gene Amplification}

Gene detection begins by making $25 \mu \mathrm{l}$ amplification consisting of $12.5 \mu \mathrm{l}$ mastermix, $1 \mu \mathrm{l}$ reverse primer, $1 \mu 1$ forward primer, $8.5 \mu \mathrm{l}$ free water nuclease free and $2 \mu 1$ bacterial DNA used as a template inserted into a micro tube $0.2 \mu 1^{9,10}$. Gene amplification was carried out by PCR in specific primers of CTX-M with thermocycling conditions as in table 1 below.

Table 1. Specific Primary CTX-M gene

\begin{tabular}{|c|c|c|c|c|c|}
\hline $\begin{array}{l}\text { Primer Name } \\
\text { Sequence }\end{array}$ & Primer & Target & Product & Thermocycling & \\
\hline & $\left(5^{\prime}\right.$ a 3') & Gene & Size (bp) & & \\
\hline \multicolumn{4}{|l|}{$\mathrm{Bla}_{\mathrm{CTX}-\mathrm{M} \mathrm{F}}$} & \multirow{2}{*}{$\begin{array}{l}\text { Denaturation } 94^{\circ} \mathrm{C}(2 \mathrm{~min}) 1 \\
\text { cycle }\end{array}$} & \\
\hline & $\begin{array}{l}\text { ATG TGC } \\
\text { AGY ACC }\end{array}$ & \multirow[t]{3}{*}{$\begin{array}{l}{ }^{\mathrm{Bla}} \mathrm{CTX}- \\
\mathrm{M}\end{array}$} & \multirow[t]{3}{*}{539} & & \\
\hline & AGT AAR & & & Amp. Denaturation (1 min) & \\
\hline & GTK ATG & & & $94{ }^{\circ} \mathrm{C}$ & \multirow{2}{*}{$\begin{array}{l}30 \\
\text { Cycle }\end{array}$} \\
\hline & GC & & & Anneling $(30 \mathrm{sec}) 52^{\circ} \mathrm{C}$ & \\
\hline \multirow[t]{5}{*}{${ }^{\mathrm{Bla} C T X-M ~ R}$} & & & & Extension $(45 \mathrm{sec}) 72^{\circ} \mathrm{C}$ & \\
\hline & TGG GTR & & & Final Extension (5 min) & \\
\hline & AAR TAR & & & $72^{\circ} \mathrm{C} \quad 1$ Cycle & \\
\hline & $\begin{array}{l}\text { GTS ACC } \\
\text { AGA AYC }\end{array}$ & & & & \\
\hline & AGC GG & & & & \\
\hline
\end{tabular}

\section{Detection of PCR Results with Agarosa Gel Electrophoresis}

As much as $2 \%$ agarose in $130 \mathrm{~mL}$ tridentetate EDTA (TAE) was heated until dissolved, then the solution was allowed to stand until warm and added $1 \mu \mathrm{L}$ of ethidium bromide (EtBr) then shaken until homogeneous then poured into a mold and allowed to stand for 30 minutes until it was completely frozen. A total of $5 \mu \mathrm{L}$ of PCR and marker samples were put 
into $2 \%$ agarose gel wells. The electrophoresis process was carried out with a potential difference of $100 \mathrm{~V}, 400 \mathrm{Ma}$ for 60 minutes. Amplified DNA that has been electrophoresed is visualized using Gel Documentation. DNA bands will be seen and their size can be determined based on molecular size markers expressed by base pairs ${ }^{11}$.

The collected data were analyzed descriptively, where positive DNA results were shown with an amplicon of 539 bp. The negative control $(\mathrm{N})$ used is sterile aquadest. The marker (M) used is a DNA ladder of $100 \mathrm{bp}$.

\section{RESULTS AND DISCUSSION}

The results of this study showed that of 50 people diagnosed with pneumonia grouped by sex, namely men with pneumonia more than 37 people (74\%) compared to women as many as 13 people (26\%). Patients with the most pneumonia are patients over 60 years old (34\%) with an average age of 63.71 years, followed by patients between 50 60 years $(26 \%)$ and the lowest age is $20-30$ years $(6 \%)$. The length of stay was 1-5 days (58\%), followed by 6-10 days (34\%) and the lowest was more than 10 days (8\%).

The results of research on 50 sputum isolates carried out by PCR method obtained 33 sputum isolates that expressed Acinetobacter baumannii (17 isolates) and Klebsiella pneumoniae (16 isolates). The distribution of resistance genes in both bacteria can be seen in the table 2 and 3 .

Table 2. CTX-M Gene Distribution in Acinetobacter baumannii

\begin{tabular}{|l|l|l|}
\hline Sample Number & Speciment & Bla CTX-M (\%) \\
\hline 7 & Sputum & $(-)$ \\
\hline 13 & Sputum & $(-)$ \\
\hline 14 & Sputum & $(-)$ \\
\hline 20 & Sputum & $(-)$ \\
\hline 22 & Sputum & $(-)$ \\
\hline 24 & Sputum & $(-)$ \\
\hline 28 & Sputum & $(-)$ \\
\hline 31 & Sputum & $(-)$ \\
\hline 32 & Sputum & $(-)$ \\
\hline 33 & Sputum & $(-)$ \\
\hline 35 & Sputum & $(-)$ \\
\hline 37 & Sputum & $(-)$ \\
\hline 38 & Sputum & $(-)$ \\
\hline 42 & Sputum & $(+)$ \\
\hline 43 & Sputum & $(+)$ \\
\hline 45 & Sputum & $(+)$ \\
\hline 47 & Sputum & $(-)$ \\
\hline Total 17 Samples & & $\mathbf{3}(\mathbf{1 7 . 6 \% )}$ \\
\hline
\end{tabular}

\section{REFERENCES}

1. Champoux J, Drew WL, Neidhardt FC, and Plorde JJ. Sherris Medical Microbiology: An Introduction to Infectious Diseases. 4th ed. United States of America: Mc.Graw Hill.Clinical and Laboratory Standard Institute; 2004.
Table 3. CTX-M Gene Distribution in Klebsiella pneumoniae

\begin{tabular}{|l|l|l|}
\hline Sample Number & Speciments & Bla CTX-M (\%) \\
\hline 1 & Sputum & $(+)$ \\
\hline 2 & Sputum & $(+)$ \\
\hline 4 & Sputum & $(+)$ \\
\hline 8 & Sputum & $(+)$ \\
\hline 10 & Sputum & $(+)$ \\
\hline 15 & Sputum & $(+)$ \\
\hline 16 & Sputum & $(+)$ \\
\hline 18 & Sputum & $(+)$ \\
\hline 19 & Sputum & $(+)$ \\
\hline 23 & Sputum & $(-)$ \\
\hline 29 & Sputum & $(+)$ \\
\hline 40 & Sputum & $(+)$ \\
\hline 42 & Sputum & $(+)$ \\
\hline 43 & Sputum & $(+)$ \\
\hline 45 & Sputum & $(+)$ \\
\hline 48 & Sputum & $(+)$ \\
\hline Total 16 samples & & $\mathbf{1 5}(\mathbf{9 3 . 7 \% )}$ \\
\hline & & \\
\hline
\end{tabular}

The expression of CTX-M is higher in Klebsiella pneumoniae because of the high prevalence of CTX-M gene in the antibiotic resistant Klebsiella pneumoniae and moreover it is found in plasmids which are components of bacteria that can be transferred between bacteria by the hyperproduction mechanism of the Amp-C enzyme. This enzyme is able to cause resistance to other antibiotics due to the deficiency of porpine OmpK35 and Ompk36 because porin is a place for hydrophilic molecules, including beta lactam, to enter the bacterial cells of Klebsiella pneumoniae $^{12-14}$.

Acinetobacter baumannii is a producer of CTX-M and is a common type of gene. The results showed that Acinetobacter Baumannii and Klebsiella pneumoniae with a high percentage of the presence of CTX-M genes. The resistant gene type CTX-M is the dominant gene in Europe, while in other countries the ESBL gene is more variable. Several studies report that ESBL types are produced by these two strains and prevalence increases with the emergence of CTXM genes ${ }^{15}$.

\section{CONCLUSSION}

The distribution of the CTX-M gene in Klebsiella pneumoniae is higher than that of Acinetobacter baumannii.

\section{CONFLICT OF INTEREST}

All author have no to declare.

2. Gassem, HM and S Setiawan. Profil klinik dan laboratorium pasien Community acquired Pneumonia sembuh dan meninggal di RSUP Dokter kardi. Jakarta: Media MedikaMuda; 2015. 
3. Riyahi, ZF, et al. The Prevalence of TEM and SHV Genes among Extended- Spectrum Beta- Lactamases Producing Escheria coli and Kleibseilla pneumoniae. Iranian Journal of Basic Medical Sciences. 2012; 15(1): 654-660.

4. Tuon FF, Kruger M, Terreri M, Penteado-Filho SR, Gortz L. Klebsiella ESBL Bacteremia Mortality and risk factors. Braz J Infect Dis. 2011; 15(6): 594-8.

5. Devinna K, Rano KS, T Rostianawati, R Abdullah. Gene blaCTX-M Mutation as Risk Factor of Antibiotic Resistance. Indonesian Journal of Clinical Pharmacy. 2017; 6(2):135-152.

6. Prasetya, YA. Identifikasi Gen Ctx-M pada Esherichia coli Penghasil Extended Spectrum Beta-Lactamases (ESBLs) di RSUD Dr. Soetomo Surabaya. Jurnal Teknologi Laboratorium. 2017; 6(2):56-60.

7. Notoatmodjo, S. (2011).Kesehatan Masyarakat Ilmu dan Seni. Jakarta: Penerbit Rineka Cipta. p 45.

8. Lisdawati, V., I Parwati, Sudarmon, TM., Sudiro, R., R. Ramadhany., N. Puspandari., et al. Studi Pemetaan Awal DNA Mycobacterium tuberculosis complex Secara Spoligo typing Pada Hasil Isolasi Dahak Pasien Tuberkulosis Paru dari 10 Kota Propinsi. Buletin Penelitian Kesehatan. 2010; 38(4):169-185

9. Rubstova MY, Ulyashova MM, Bachmann TT, Schmid RD, Egorov AM. Multiparametric Determination Of Genes And Their Point Mutations For Identification Of Betalactamase. Biochemistry. 2010; 75(13):1628-49.
10. Hout B. et al. Drug resistance in bacteria Isolated from Patients Presenting with Wounds At A Nonprofit Surgical Center in Phnom Penh, Cambodia from 2011-2013. Tropical Diseases Travel Medicine and Vaccines. 2015; 1(4).

11. Murakami K., W Minamide, K Wada, E Nakamura, H Teraoka, S Watanabe. Identification of Methicillin-Reistant Strains of Staphylococci by Poymerase Chain Reaction. Journal of Clinical Microbiology. 1991; 2(10):2240-2244.

12. Kaczmarek, FM,. F Dibb-Hajj, W Shang, TD Gootz. High Level Carbapenem Resistance in Klebsiella pneumoniae Clinical Isolate is Due to the Combination of blaACT-1 $\beta$-Lactamase Production, Porin OmpK35/36 Insertional Inactivation, and Down-Regulation of the Phosphate Transport Porin PhoE. Antimicrobial Agent and Chemotherapy. 2006; 50(10):3396-3406.

13. Shin SY, IK Bae, J Kim, SH Jeong, D Yong, JM Kim, K Lee. Resistance to Cabapenems in Sequence Type 11 Klebsiella pneumoniae is Relates to DHA-1 and Loss of OmpK35 and/or OmpK36. Journal of Medical Microbiology. 2012; 61(2):239-245.

14. Palasubramaniam $S, S$ Muniandy, $P$ Navartnam. Resistance to ExtendedSpectrum $\beta$-Lactams by the Emergence of SHV-12 and the Loss of OmpK35 in Klebsiella pneumoniae and Escherichia coli in Malaysia. J Microbiol Immunol Infect. 2009; 42:129-133.

15. Paterson DL, RA Bonomo. Extended-Spectrum $\beta$-Lactamases: a Clinical Update. Clinical Microbiology Journal. 2005; 18(4):658-686. 